\title{
Substituted 3-acyl-2-phenylamino-1,4-naphthoquinones intercalate into DNA and cause genotoxicity through the increased generation of reactive oxygen species culminating in cell death
}

\author{
MIRELLE SIFRONI FARIAS ${ }^{1}$, CLAUS TRÖGER PICH ${ }^{2}$, MAICON ROBERTO KVIECINSKI ${ }^{1}$, \\ NÁDIA CRISTINA FALCÃO BUCKER ${ }^{1}$, KARINA BETTEGA FELIPE ${ }^{1}$, FABIANA OURIQUE DA SILVA ${ }^{1}$, \\ TÂNIA MARA FISHER GÜNTHER ${ }^{1}$, JOÃO FRANCISCO CORREIA ${ }^{1}$, DAVID RÍOS ${ }^{3}$, JULIO BENITES ${ }^{3}$, \\ JAIME A. VALDERRAMA ${ }^{3,4}$, PEDRO BUC CALDERON ${ }^{3,5}$ and ROZANGELA CURI PEDROSA ${ }^{1}$ \\ ${ }^{1}$ Laboratory of Experimental Biochemistry, Department of Biochemistry, Federal University of Santa Catarina, Florianópolis, \\ Santa Catarina 88040-900; ${ }^{2}$ Campus Araranguá, University of Santa Catarina, Araranguá 88900-000, Brazil; \\ ${ }^{3}$ Faculty of Health Sciences, University of Arturo Prat, Iquique 1100000; ${ }^{4}$ Faculty of Chemistry, Pontifical Catholic \\ University of Chile, Santiago 8320000, Chile; ${ }^{5}$ Toxicology and Cancer Biology Research Group, \\ Louvain Drug Research Institute, Université Catholique de Louvain, Brussels 1348, Belgium
}

Received September 21, 2013; Accepted March 17, 2014

DOI: $10.3892 / \mathrm{mmr} .2014 .2160$

\begin{abstract}
Naphthoquinones interact with biological systems by generating reactive oxygen species (ROS) that can damage cancer cells. The cytotoxicity and the antitumor activity of 3-acyl-2-phenylamino-1,4-naphthoquinones (DPB1-DPB9) were evaluated in the MCF7 human breast cancer cell line and in male Ehrlich tumor-bearing Balb/c mice. DPB4 was the most cytotoxic derivative against $\mathrm{MCF} 7$ cells $\left(\mathrm{EC}_{50} 15 \mu \mathrm{M}\right)$ and DPB6 was the least cytotoxic one $\left(\mathrm{EC}_{50} 56 \mu \mathrm{M}\right)$. The 1,4-naphthoquinone derivatives were able to cause DNA damage and promote DNA fragmentation as shown by the plasmid DNA cleavage assay (FII form). In addition, 1,4-naphthoquinone derivatives possibly interacted with DNA as intercalating agents, which was demonstrated by the changes caused in the fluorescence of the DNA-ethidium bromide complexes. Cell death of MCF7 cells induced by 3-acyl-2-phenylamino-1,4-naphthoquinones was mostly due to apoptosis. The DNA fragmentation and subsequent apoptosis may be correlated to the redox potential of the 1,4-naphthoquinone derivatives that, once present in the cell nucleus, led to the increased generation of ROS. Finally, certain 1,4-naphthoquinone derivatives and particularly DPB4
\end{abstract}

Correspondence to: Dr Rozangela Curi Pedrosa, Laboratory of Experimental Biochemistry, Department of Biochemistry, Federal University of Santa Catarina, Campus Trindade, Florianópolis, Santa Catarina 88040-900, Brasil

E-mail: roza@ccb.ufsc.br

Key words: 3-acyl-2-phenylamino-1,4-naphthoquinones, reactive oxygen species generation, DNA fragmentation, cytotoxicity, apoptosis, antitumor effect significantly inhibited the growth of Ehrlich ascites tumors in mice $(73 \%)$.

\section{Introduction}

Cancer is a heterogeneous group of diseases resulting from accumulated genetic changes. Data from the World Health Organization demonstrate that these diseases are the main cause of death in economically developed countries and the second leading cause of death in developing countries (1). Although chemotherapy is currently the most common treatment regimen for the majority of cancers, several chemotherapies exhibit a low therapeutic index, resulting in serious side effects (2). For this reason, studies in the field of cancer therapy have led to the development of novel drugs that aim to maximize the effectiveness against cancer, to avoid the side effects and to prevent multidrug resistance (3).

Among numerous natural and synthetic compounds that were investigated for their anticancer potential, compounds containing quinone moieties, including doxorubicin and other anthracyclines, are widely used as efficient anticancer drugs (4). The drugs' main mechanisms of action are thought to involve: i) A direct interaction with DNA; ii) topoisomerase inhibition; and iii) generation of reactive oxygen species $(5,6)$. However, their use is limited by side effects, such as cardiotoxicity (7). Quinones and particularly 1,4-naphthoquinones are abundant in nature and display diverse pharmacological properties, including antibacterial, antifungal, antiviral, anti-inflammatory, antipyretic and anticancer activities $(8,9)$. The presence of electron-donating or electron-withdrawing substituents linked to the vinyl double bond of 1,4-naphthoquinones modulates the generation of quinone radical anion species. The redox properties of the radical anion species enable these compounds to undergo a catalytic cycle and in the presence of molecular oxygen they generate reactive oxygen 
species (ROS), including hydrogen peroxide and superoxide anions, which damage the DNA and certain essential proteins. These agents represent a promising approach for targeting cancer cells (10-12). Indeed, as a result of metabolic changes and oncogene activation, cancer cells generally exhibit high levels of ROS, which can stimulate cell proliferation and promote genetic instability (13). Additionally, it has been revealed that cancer cells exhibit a low antioxidant defense activity compared with healthy cells (14). The biochemical differences between normal and cancer cells represent a specific vulnerability that can be selectively targeted in cancer therapy.

The aim of the present study was to evaluate the activity of a variety of 3-acyl-2-phenylamino-1,4-naphthoquinones (Fig. 1) in order to obtain insights into the influence of the combined electronic donor/acceptor effects (known as push-pull) of the phenylamine/acyl substituents, located at the vinyl double bond of the 1,4-naphthoquinone core, on the survival (including the cell death mechanism) of MCF7 breast cancer cells and Ehrlich ascites tumor growth in a mouse model. Additional assays were performed to assess the physical interaction of these compounds with plasmid DNA and their DNA intercalation properties.

\section{Materials and methods}

Chemicals. Dulbecco's modified Eagle's medium (DMEM), fetal bovine serum (FBS) and antibiotics were purchased from Cultilab (Campinas, SP, Brazil). Dimethylsulfoxide (DMSO), dichlorofluorescein diacetate (DCFH-DA), agarose, distamycin, catalase, calf thymus DNA (CT-DNA), $\mathrm{N}$-acetylcysteine and bovine serum albumin were purchased from Sigma-Aldrich (Sigma-Aldrich, St. Louis, MO, USA). The annexin V-fluorescein isothiocyanate (FITC) apoptosis detection kit was purchased from BD Pharmingen (San Diego, CA, USA). The Perfectprep Plasmid Mini extraction kit was purchased from Eppendorf (Hamburg, Germany). All the other chemicals ACS grade reagents.

General procedure for the preparation of 3-acyl-2-phenylamino-1,4-naphthoquinones. The preparation of the core 3-acyl-2-phenylamino-1,4-naphthoquinones was initiated with the synthesis of 2-acylnaphthohydroquinones via solar-induced Photo-Friedel-Crafts acylation of 1,4-naphthoquinone with aldehydes according to a previously reported procedure (12). The resulting compounds were then oxidized with silver (I) oxide in dichloromethane, and the corresponding 2-acyl-1,4-naphthoquinones were reacted in situ with selected phenylamines in a one-step procedure to produce the corresponding 3-acyl-2-phenylamino-1,4-naphthoquinones DPB1-DPB9 (Fig. 1) (15). The quinone structures were confirmed by comparing their infrared and proton/carbon nuclear magnetic resonance spectral properties to those reported in the literature (15).

\section{In vitro assays}

Cytotoxicity assays. The MCF7 human breast carcinoma cells were obtained from the Rio de Janeiro Cell Bank (Rio de Janeiro, Brazil). The cells were cultured at $37^{\circ} \mathrm{C}$ in the presence of $5 \% \mathrm{CO}_{2}$ and $95 \%$ humidity. DMEM supplemented with $10 \% \mathrm{FBS}$, penicillin $(100 \mathrm{U} / \mathrm{ml})$ and streptomycin $(100 \mu \mathrm{g} / \mathrm{ml})$ was used as the culture medium. The cytotoxic effect of 3-acyl-2-phenylamino-1,4-naphthoquinones on breast cancer cells was tested using the MTT assay as described previously (16). Briefly, $10^{4}$ cells/well were plated in 96-well plates. After reaching confluence, the cells were exposed to the respective 3-acyl-2-phenylamino-1,4-naphtoquinones $(0-80 \mu \mathrm{M})$ for up to $24 \mathrm{~h}$. The cells were then washed twice with phosphate-buffered saline (PBS) and incubated for $2 \mathrm{~h}$ with MTT $(0.5 \mathrm{mg} / \mathrm{ml})$. The formazan crystals were solubilized by adding DMSO (100 $\mu \mathrm{l} /$ well) and the absorbances of the colored solutions were read at $550 \mathrm{~nm}$.

Plasmid DNA cleavage. The plasmid DNA cleavage assay was performed as previously described by Günther et al (17) with minor adaptations. For this assay, the supercoiled PUC 9.1 plasmid DNA was isolated from the DH5S $\alpha$ FIQ Escherichia coli strain using a Maxi Prep kit (Qiagen, Hilden, Germany) and according to the manufacturer's instructions. The plasmid DNA (600 ng) was treated with the test compounds $(0.05 \mu \mathrm{M})$ in hydroxyethyl-piperazineethanesulfonic acid (HEPES) buffer at $\mathrm{pH} 7.4$ for $16 \mathrm{~h}$ in the dark at $37^{\circ} \mathrm{C}$. The samples were electrophoresed for $40 \mathrm{~min}$ at $90 \mathrm{~V}$ on a $0.8 \%$ agarose gel in Tris-borate-ethylenediaminetetraacetic acid buffer. The gel was stained with $0.5 \mu \mathrm{g} / \mathrm{ml}$ ethidium bromide and then visualized and photographed under ultraviolet light. The images were analyzed using ImageJ 1.46 bioinformatics software (National Institute of Health, Bethesda, MD, USA) in order to compare the band intensity and the pixel number presented by the supercoiled intact form (FI), open circular (single strand break - FII) and linear plasmid form (double strand break - FIII). Furthermore, the DNA intensity of the FI form was corrected by a factor of 1.47 due to its reduced ability to be stained by ethidium bromide (18).

Intercalation assay. In order to determine whether the 3-acyl-2-phenylamino-1,4-naphthoquinones interact with CT-DNA by intercalation, the DNA-intercalating agent ethidium bromide was used (18). The CT-DNA was diluted with $50 \mathrm{mM}$ phosphate buffer containing $0.1 \mathrm{M} \mathrm{NaCl}(\mathrm{pH} 7.4) . \mathrm{NaCl}$ was included to avoid second binding of ethidium bromide to the DNA. The concentration of CT-DNA used was $20 \mu \mathrm{M}$. The emission spectrum of ethidium bromide in the presence and absence of DNA was recorded at concentrations in the range of $10-110 \mu \mathrm{M}$ in order to identify the saturation point of the DNA sites corresponding to the binding of this compound. Once the saturating concentration of ethidium bromide was established $(30 \mu \mathrm{M})$, the fluorescence absorbance was measured using increasing concentrations of 3-acyl-2-phenylamino-1,4 naphthoquinones (DPB1, DPB2, DPB4 and DPB5). The absorbance was recorded at room temperature $10 \mathrm{~min}$ after the addition of the compounds. A TECAN Infinite M200 fluorescence reader (Tecan Austria GmbH, Grödje, Austria) was used for the measurements using a protocol adapted from Silveira et al (19). The excitation wavelength used was $492 \mathrm{~nm}$ and the emitted fluorescence was measured at $\sim 620 \mathrm{~nm}$.

Intracellular ROS determination. Intracellular ROS were evaluated according to the procedure described by 


\section{3-acyl-2-phenylamino-1,4-naphthoquinone}<smiles>[R]c1ccc(NC2=C(C(=O)O)C(=O)c3ccccc3C2=O)cc1</smiles>

\begin{tabular}{c|c|c|c|c|c|c|c|c|c} 
& DPB1 & DPB2 & DPB3 & DPB4 & DPB5 & DPB6 & DPB7 & DPB8 & DPB9 \\
\hline $\mathrm{R}^{1}$ & $\mathrm{Me}$ & $\mathrm{Me}$ & $\mathrm{Me}$ & $\mathrm{O}^{\mathrm{O}}$ & - & ${ }^{\mathrm{O}}$ & $\mathrm{U}^{\mathrm{S}}$ & $\mathrm{U}^{\mathrm{S}}$ & $\mathrm{N}^{\mathrm{S}}$ \\
\hline $\mathrm{R}^{2}$ & $\mathrm{H}$ & $\mathrm{OMe}$ & $\mathrm{NO}_{2}$ & $\mathrm{H}$ & $\mathrm{OMe}$ & $\mathrm{NO}_{2}$ & $\mathrm{H}$ & $\mathrm{OMe}$ & $\mathrm{NO}_{2}$
\end{tabular}

Figure 1. Chemical structures of 3-acyl-2-phenylamino-1,4-naphthoquinones.

Glorieux et al (20). The cells $(15,000)$ were loaded with $10 \mu \mathrm{M}$ DCFH-DA in Hank's balanced salt solution (HBSS) at $37^{\circ} \mathrm{C}$ and incubated for $30 \mathrm{~min}$. Excess DCFH-DA was removed by washing with fresh Hank's buffer solution HBSS. The cells were then incubated for $2 \mathrm{~h}$ with the test compounds, washed twice more with HBSS and then $100 \mu 1$ of HBSS/well was added. The fluorescence intensity of dichlorofluorescein was measured at an excitation wavelength of $485 \mathrm{~nm}$ and an emission wavelength of $520 \mathrm{~nm}$. Changes in the ROS levels were determined by calculating $\Delta \mathrm{F}=(\mathrm{Ft}-\mathrm{Fc}) / \mathrm{Fc}$, where $\mathrm{Ft}$ represents the fluorescence read at each time-point and $\mathrm{Fc}$ the control fluorescence.

Assessment of the mechanism of apoptosis. Apoptosis was quantified using an annexin V-FITC apoptosis detection kit from BD Pharmingen (San Diego, CA, USA), which detects phosphatidylserine that is externalized during the early phases of apoptosis. Briefly, MCF7 cells were plated at a density of $10^{6}$ cells/well in 12 -well plates. Subsequent to an overnight incubation, the cells were treated with 3-acyl-2-phenylamino-1,4-naphthoquinones $(15 \mu \mathrm{M})$ for $24 \mathrm{~h}$. The negative control was treated with $0.25 \%$ DMSO in fresh culture medium. The cells were then washed with PBS (three times) at $37^{\circ} \mathrm{C}$, trypsinized, washed again with PBS (three times) at $37^{\circ} \mathrm{C}$ and then resuspended in $200 \mu \mathrm{l}$ binding buffer [0.1 M HEPES/NaOH (pH 7.4), 1.4 M NaCl and $25 \mathrm{mM} \mathrm{CaCl}_{2}$ ] diluted 1:10 in distilled water. Next, $5 \mu \mathrm{l}$ annexin V-FITC was added and the samples were incubated for $15 \mathrm{~min}$ in the dark. Finally, $5 \mu \mathrm{l}$ propidium iodide was added and flow cytometric analysis was performed. The fluorescence intensities of annexin V-FITC and propidium iodide were measured using a $488 \mathrm{~nm}$ excitation filter, and the emission was detected in the range of 515-545 $\mathrm{nm}$ and 564-606 nm, respectively. The data were analyzed using the WinMDI software (BD Pharmingen).

\section{In vivo antitumor activity}

Animals and treatments. Male isogenic Balb/c mice weighing $20 \pm 2 \mathrm{~g}$ were housed under controlled conditions (12-h light/dark cycle, $21 \pm 2^{\circ} \mathrm{C}, 60 \%$ humidity) and had free access to standard food and water. All the animals were allowed to acclimatize for at least five days prior to the first treatment. The animals fasted for $12 \mathrm{~h}$ prior to the treatment with water provided ad libitum. All the animal procedures were conducted in accordance with legal requirements appropriate to the species (NIH publication no. 80-23, revised in 1978) and with approval from the local ethics committee (CEUA-PP00744) of the University of Santa Catarina (Florianópolis, Brazil).

The Ehrlich ascites carcinoma $\left(5 \times 10^{6}\right.$ cells $)$ were inoculated in the peritoneum of mice under aseptic conditions; this time-point was regarded as day zero. The animals were divided into six groups $(\mathrm{n}=6)$ : A negative control treated with $0.9 \% \mathrm{NaCl}$ (50 $\mu \mathrm{l})$; a positive control treated with doxorubicin $(1.2 \mathrm{mg} / \mathrm{kg})$; plus four test-groups treated with DPB1, DPB2, DPB4 and DPB5 $(0.16 \mathrm{mg} / \mathrm{kg})$, respectively. The intraperitoneal treatments began $24 \mathrm{~h}$ after tumor inoculation and they were repeated every $24 \mathrm{~h}$ for nine days. On day ten, all the animals were anesthetized and sacrificed by cervical dislocation.

Inhibition of tumor growth. The inhibition of tumor growth was determined by measuring the change in the abdominal circumference of mice between day zero and day ten based on previously reported methods (21). The following formula was used: Inhibition of tumor growth $(\%)=[$ (variation in waist circumference of the treated group $\mathrm{x} 100)$ / variation in waist circumference of the control group] - 100.

Data analysis. The assays were performed in triplicate and in vitro assays were repeated at least three times. Unless otherwise specified, values are expressed as the mean \pm standard deviation. Data were analyzed for statistical differences using the one-way analysis of variance test followed by the Bonferroni test. The $\mathrm{EC}_{50}$ values were determined using the GraphPad Prism software (San Diego, CA, USA). Differences between values with $\mathrm{P}<0.05$ were considered statistically significant.

\section{Results and Discussion}

Cytotoxic effect of 3-acyl-2-phenylamino-1,4-naphthoquinones on MCF7 cells. The $\mathrm{EC}_{50}$-values obtained following incubation of MCF7 cells for $24 \mathrm{~h}$ with 3-acyl-2-phenylamino-1,4-naphthoquinones at different concentrations (5-80 $\mu \mathrm{M})$ are shown in Table I. The quinones exerted significant cytotoxic effects $\left(\mathrm{EC}_{50}<60 \mu \mathrm{M}\right)$. DPB4 was the most cytotoxic $\left(\mathrm{EC}_{50} 15.0 \mu \mathrm{M}\right)$ and DPB6 $\left(\mathrm{EC}_{50} 56.0 \mu \mathrm{M}\right)$ the least cytotoxic compound. The differences in the $\mathrm{EC}_{50}$-values indicated that the nature of the substituent group influences the cytotoxicity of these quinones. A previous study showed that changes in the quinoid core alter 
Table I. $\mathrm{EC}_{50}$ values obtained by the MTT reduction assay. MCF7 cells were treated for $24 \mathrm{~h}$ with 3-acyl-2-phenylamino-1,4-naphthoquinones (5-80 $\mu \mathrm{M})$.

\begin{tabular}{lc}
\hline Compounds & $\mathrm{EC}_{50}, \mu \mathrm{M}$ \\
\hline DPB1 & $20.3 \pm 1.8$ \\
DPB2 & $22.6 \pm 8.0$ \\
DPB3 & $48.6 \pm 6.6$ \\
DPB4 & $15.0 \pm 8.5$ \\
DPB5 & $23.9 \pm 8.1$ \\
DPB6 & $56.0 \pm 8.7$ \\
DPB7 & $34.8 \pm 8.2$ \\
DPB8 & $28.6 \pm 7.5$ \\
DPB9 & $30.1 \pm 5.5$ \\
\hline
\end{tabular}

Experiments were performed in triplicate and the results are expressed as the mean \pm standard deviation.

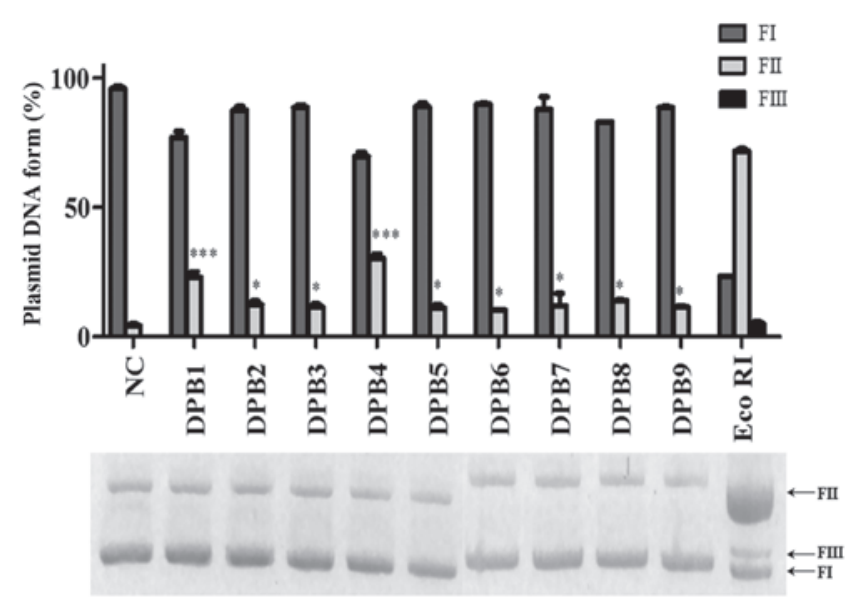

Figure 2. DNA plasmid damage induced by 3-acyl-2-phenylamino-1,4-naphthoquinones (DPB1-DPB9). Experiments were performed in triplicate, and the results are expressed as the mean \pm standard deviation of the percentage of the plasmid DNA form observed. Left-hand lane, NC of DNA treated with vehicle alone (dimethylsulfoxide); right-hand lane, EcoRI, positive control DNA treated with vehicle and the restriction enzyme EcoRI. Significant differences between the treated and the NC groups are denoted by " and ${ }^{* * *}$, indicating $\mathrm{P}<0.1$ and $\mathrm{P}<0.001$, respectively. $\mathrm{NC}$, negative control; FI, supercoiled intact form; FII, open circular form resulting from a single-strand break; FIII, linear plasmid form resulting from a double-strand break.

the cytotoxicity of quinones in a panel of cancer cells (MCF7, DU145, T24, J82, AGS, and BEM-SK-1) and impair the proliferative capacity of T24 cells (12). Additionally, the electronic properties of the substituent bound to the quinone core may interfere with the redox cycling process and thus affect the production of ROS (11).

Cleavage of plasmid DNA by 3-acyl-2-phenylamino-1,4naphthoquinone. It was demonstrated that the 3-acyl-2-phenylamino-1,4-naphthoquinones at $0.05 \mu \mathrm{M}$ were able to cause mild plasmid DNA fragmentation (Fig. 2). In parallel with the cytotoxicity results, DPB1 and DPB4 were the most genotoxic compounds. They caused single-strand breaks in the DNA as indicated by the appearance of bands of the FII DNA form at

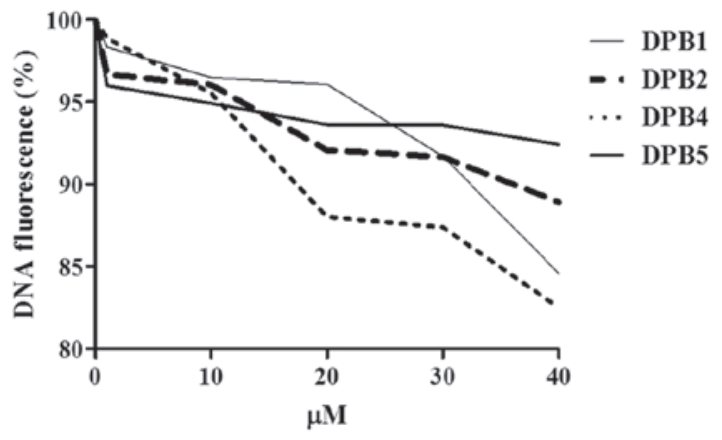

Figure 3. The intercalating ability of 3-acyl-2-phenylamino-1,4-naphthoquinones. The 3-acyl-2-phenylamino-1,4-naphthoquinones (DPB1, DPB2, DPB4 and DPB5) alone $(1,10,20,30$ and $40 \mu \mathrm{M})$ were evaluated via the fluorescence intensity of ethidium bromide $(30 \mu \mathrm{M})$ bound to the CT-DNA $(20 \mu \mathrm{M})$. CT-DNA, calf thymus DNA.

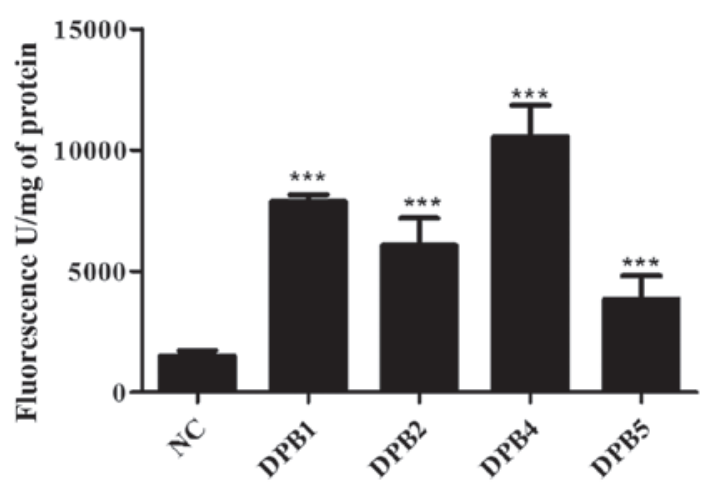

Figure 4. Intracellular ROS induced by 3-acyl-2-phenylamino-1,4-naphthoquinones $(15 \mu \mathrm{M})$. Significant differences between the treated and the NC groups are denoted by ${ }^{* * *}$, indicating $\mathrm{P}<0.001$. ROS, reactive oxygen species; $\mathrm{NC}$, negative control treated with medium + dimethylsulfoxide $(0.25 \%)$.

ratios of 22 and $30 \%$, respectively. EcoRI was used as the positive control, causing $71 \%$ of DNA single-strand cleavage resulting in the open circular form (FII) and 5\% double-strand cleavage resulting in the linear FIII form.

DNA strand breaks compromise the integrity of the genetic information and therefore decrease the cell viability. It is likely that 3-acyl-2-phenylamino-1,4-naphthoquinones exert cytotoxic effects resulting in apoptosis of tumor cells since they can induce DNA fragmentation.

DNA intercalation bycertain 3-acyl-2-phenylamino-1,4-naphthoquinones. The fluorescence spectra of CT-DNA/ethidium bromide associated with 3-acyl-2-phenylamino-1,4 naphthoquinones $(1-40 \mu \mathrm{M})$ were evaluated to check whether these compounds have an intercalating activity. Substances able to intercalate into DNA cause a reduction in the amount of ethidium bromide bound to DNA with respective decreases in their fluorescence intensity (18). It was demonstrated that 3-acyl-2-phenylamino-1,4 napthoquinones decreased the fluorescence intensity in a concentration-dependent manner (Fig. 3). Thus, they are capable of intercalating into DNA. DPB4 caused the strongest reduction in ethidium bromide fluorescence; thus it is expected to have the strongest intercalating activity as compared to DPB1, DPB2 and DPB5 (Fig. 3). It is known that doxorubicin, besides acting as a nuclease by 
Table II. Types of MCF7 cell death induced by 3-acyl-2-phenylamino-1,4-naphthoquinones (15 $\mu \mathrm{M})$ administered for $24 \mathrm{~h}$.

\begin{tabular}{lccccc}
\hline & & & \multicolumn{3}{c}{ Apoptotic cells (\%) } \\
\cline { 4 - 6 } Treatments & Viable cells, \% & Necrotic cells, $\%$ & Initial apoptosis & Late apoptosis & Total apoptotic cells \\
\hline Negative control & 98.1 & 0.0 & 0.5 & 1.5 & 1.9 \\
DPB1 & 77.1 & 5.0 & 8.1 & 9.8 & 18.0 \\
DPB2 & 82.1 & 5.8 & 2.1 & 10.0 & 12.1 \\
DPB4 & 78.1 & 2.5 & 5.5 & 13.9 & 19.4 \\
DPB5 & 85.5 & 6.4 & 0.7 & 7.4 & 8.1 \\
\hline
\end{tabular}

NC, negative control treated with medium + dimethylsulfoxide $(0.25 \%)$.

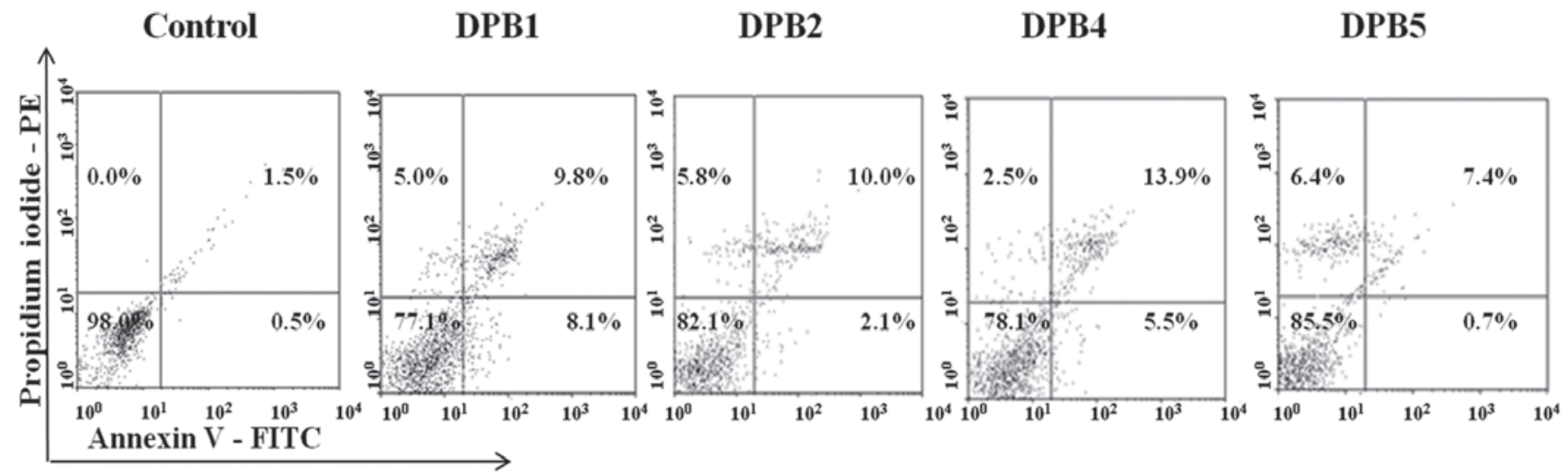

Figure 5. Types of MCF7 apoptosis induced by 3-acyl-2-phenylamino-1,4-naphthoquinones ( $15 \mu \mathrm{M})$ administered for $24 \mathrm{~h}$. NC, negative control treated with medium + dimethylsulfoxide $(0.25 \%)$; FITC, fluorescein isothiocyanate.

an oxidative mechanism, also acts through a non-specific DNA-intercalating action $(22,23)$, similar to that observed for 3-acyl-2-phenylamino-1,4 naphthoquinones. Intercalating agents may be useful in treating cancer since they exhibit antiproliferative effects. Once these agents are present between the DNA strands, they can block DNA replication and cell proliferation. Several cellular mechanisms may be triggered under such conditions, leading either to cell death or senescence. p53 is activated to induce DNA repair and if this is not effective, apoptosis occurs.

Intracellular ROS levels. MCF7 cells exposed to 3-acyl-2-phenylamino-1,4-naphthoquinones revealed increased intracellular levels of ROS compared with the negative control (Fig. 4). In cells exposed to DPB4 and DPB1, the content of intracellular ROS was found increased up to 10 and 8-fold, respectively (Fig. 4).

A study by Verrax et al (24) indicated that the potential of the majority of quinone derivatives to induce the generation of cellular ROS should depend on their redox potential.

Mechanisms of cell death. The treatment of MCF-7 cells with 3-acyl-2-phenylamino-1,4-naphthoquinones increased the frequency of both apoptotic and necrotic cells in comparison to the negative control (Fig. 5 and Table II). Apoptosis was identified to be the main mechanism underlying induced cell

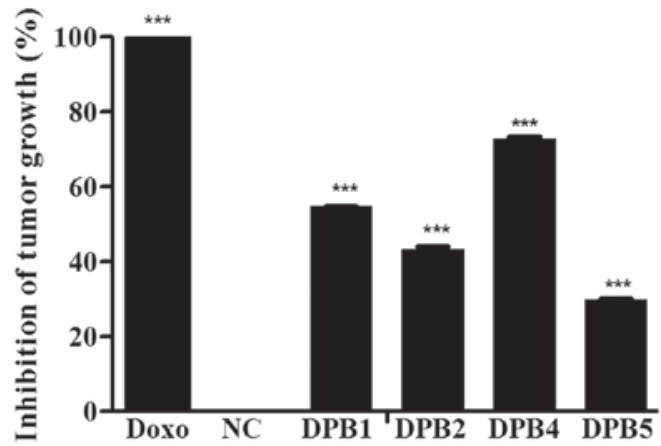

Figure 6. Inhibition of tumor growth following treatment with DPB1, DPB2, DPB4 or DPB5. DPB1, DPB2, DPB4 and DPB5 were injected intraperitoneally at a concentration of $0.16 \mathrm{mg} / \mathrm{kg} /$ day in mice bearing Ehrlich ascites tumors, based on the variation in waist circumference. The results are expressed as the mean \pm standard deviation, $n=6$. Significant differences between the treated and the $\mathrm{NC}$ groups are denoted by ${ }^{* * * *}$, indicating $\mathrm{P}<0.001$. $\mathrm{NC}$, negative control; Doxo, doxorubicin (positive control).

death. Particularly, cells were found mostly in the stage of late apoptosis.

Although apoptosis induced by 3-acyl-2-phenylamino-1,4-naphthoquinones could have been triggered by the intercalation into DNA, it is also well-known that increased levels of ROS can culminate in both apoptosis and necrosis $(25,26)$. For instance, a previous study demonstrated 
that juglone (5-hydroxy-1,4-naphthoquinone) induced apoptotic death in HL60 leukemia cells, and this effect was avoided in the presence of the antioxidants $N$-acetylcysteine and catalase (27). A study indicated that the oxidative stress induced by certain quinones can lead to cell death either through necrosis or apoptosis, depending on the concentration and exposure time to the oxidizing agent, as well as the cell type (28). DPB4 exerts strong antitumor effects due to its ability to kill cancer cells via intercalating into DNA and by increasing the generation of ROS that cleave DNA. All these events culminate in increased levels of apoptosis and necrosis (Fig. 5 and Table II) and they are involved in the mechanism underlying the cytotoxicity of the series of 3-acyl-2-phenylamino-1,4-naphthoquinones investigated in the present study.

Antitumor effect in vivo. The effects of the 3-acyl-2-phenylamino-1,4-naphthoquinones against the Ehrlich ascites carcinoma in mice are shown in Fig. 6. All the 3-acyl-2-phenylamino-1,4-naphthoquinones that were assayed presented a certain effect as compared with the negative control. DPB4 was initially indicated by the in vitro assays to be the most potent compound, and was also confirmed to be the most promising candidate in vivo, as it was capable of reducing tumor growth by up to $70 \%$. Once the results are confirmed, it will be possible to predict whether DNA intercalation and the increased ROS generation are not constrained in vivo by antioxidant defenses, by the immune system or by drug biotransformation. Due to its potency in the present study, DPB4 was selected as a potential prototype for further studies in the development of a novel antitumor drug.

\section{Acknowledgements}

This study was supported by grants from CNPq/MCT-Brazil. R.C. Pedrosa (Proc. 302404/2011-2) is a recipient of a research grant from the National Research Council of Brazil. M.S. Farias, K.B. Felipe, F.O. da Silva and N.F. Bücker are fellows from CAPES, Brazil. The authors would also like to thank the National Fund of Science and Technology (FONDECYT grant no. 1100376) in Chile for financial support that was provided for the synthetic experiments performed in this investigation.

\section{References}

1. Jemal A, Bray F, Center MM, Ferlay J and Forman D: Global cancer statistics. CA Cancer J Clin 61: 69-90, 2011.

2. Adams VR: Adverse events associated with chemotherapy for common cancers. Pharmacotherapy 20: S96-S103, 2000.

3. Schwartz J: Current combination chemotherapy regimens for metastatic breast cancer. Am J Health Syst Pharm 66 (Suppl 6): S3-S8, 2009.

4. Nadas J and Sun D: Anthracyclines as effective anticancer drugs. Expert Opin Drug Discov 1: 549-568, 2006.

5. Carvajal D, Kennedy S, Boustani A, et al: Induction of cell death by a novel naphthoquinone containing a modified anthracycline ring system. Chem Biol Drug Des 78: 764-777, 2011.

6. Gholivand MB, Kashanian S and Peyman H: DNA-binding, DNA cleavage and cytotoxicity studies of two anthraquinone derivatives. Spectrochim Acta A Mol Biomol Spectrosc 87: 232-240, 2012.

7. Zucchi R and Danesi R: Cardiac toxicity of antineoplastic anthracyclines. Curr Med Chem Anticancer Agents 3: 151-71, 2003.
8. Babula P, Adam V, Havel L and Kizek R: Naphthoquinones and their pharmacological properties. Ceska Slov Farm 56: 114-120, 2007 (Article in Czech).

9. Kviecinski MR, Pedrosa RC, Felipe KB, et al: Inhibition of cell proliferation and migration by oxidative stress from ascorbate-driven juglone redox cycling in human bladder-derived T24 cells. Biochem Biophys Res Commun 421: 268-273, 2012.

10. Smith MT: Quinones as mutagens, carcinogens, and anticancer agents: introduction and overview. J Toxicol Environ Health 16: 665-672, 1985 .

11. Benites J, Valderrama JA, Taper $\mathrm{H}$ and Buc Calderon P: Part 2: influence of 2-euryfuryl-1,4-naphthoquinone and its peri-hydroxy derivatives on both cell death and metabolism of TLT cells, a murine hepatoma cell line. Modulation of cytotoxicity by vitamin C. Chem Pharm Bull 57: 615-619, 2009.

12. Benites J, Ríos D, Díaz $P$ and Valderrama J: The solar-chemical-Friedel-Crafts heteroacylation of 1,4-quinones. Tetrahedron Lett 52: 609-611, 2011.

13. Trachootham D, Zhou Y, Zhang H, et al: Selective killing of oncogenically transformed cells through a ROS-mediated mechanism by beta-phenylethyl isothiocyanate. Cancer Cell 10: 241-252, 2006

14. Verrax J, Beck R, Dejeans N, et al: Redox-active quinones and ascorbate: an innovative cancer therapy that exploits the vulnerability of cancer cells to oxidative stress. Anticancer Agents Med Chem 11: 213-221, 2011.

15. Ríos D, Benites J, Valderrama JA, et al: Biological evaluation of 3-acyl-2-arylamino-1,4-naphthoquinones as inhibitors of Hsp90 chaperoning function. Curr Top Med Chem 12: 2094-2102, 2012.

16. Mosmann T: Rapid colorimetric assay for cellular growth and survival: application to proliferation and cytotoxicity assays. J Immunol Methods 16: 55-63, 1983.

17. Günther TMF, Kviecinski MR, Baron CC, et al: Sodium orthovanadate associated with pharmacological doses of ascorbate causes an increased generation of ROS in tumor cells that inhibits proliferation and triggers apoptosis. Biochem Biophys Res Commun 430: 883-888, 2013.

18. Sreedhara A and Cowan JA: Catalytic hydrolysis of DNA by metal ions and complexes. J Biol Inorg Chem 4: 337-347, 2001.

19. da Silveira VC, Benezra H, Luz JS, et al: Binding of oxindole-Schiff base copper (II) complexes to DNA and its modulation by the ligand. J Inorg Biochem 105: 1692-1703, 2011.

20. Glorieux C, Dejeans N, Sid B, et al: Catalase overexpression in mammary cancer cells leads to a less aggressive phenotype and an altered response to chemotherapy. Biochem Pharmacol 15: 1384-1390, 2011.

21. Kviecinski MR, Benelli P, Felipe KB, et al: SFE from Bidens pilosa Linné to obtain extracts rich in cytotoxic polyacetilenes with antitumor activity. J Supercrit Fluid 56: 243-248, 2010.

22. Neidle S: The molecular basis for the action of some DNA-binding drugs. Prog Med Chem 16: 151-221, 1979.

23. Kennedy S, DiCesare JC and Sheaff RJ: Topoisomerase I/II inhibition by a novel naphthoquinone containing a modified anthracycline ring system. Biochem Biophys Res Commun 408: 94-98, 2011.

24. Verrax J, Delvaux M, Beghein N, et al: Enhancement of quinone redox cycling by ascorbate induces a caspase-3 independent cell death in human leukaemia cells. An in vitro comparative study. Free Radic Res 39: 649-657, 2005.

25. Deeb D, Gao X, Jiang H, et al: Oleanane triterpenoid CDDO-Me inhibits growth and induces apoptosis in prostate cancer cells through a ROS-dependent mechanism. Biochem Pharmacol 79: 350-360, 2010

26. Hyun MS, Hur JM, Mun YJ, Kim D and Woo WH: BBR induces apoptosis in HepG2 cell through an Akt-ASK1-ROS-p38MAPKs-linked cascade. J Cell Biochem 109: 329-338, 2010.

27. Xu HL, Yu JF, Qu SC, Jiang YF and Sui da Y: Juglone, from Juglans mandshruica Maxim, inhibits growth and induces apoptosis in human leukemia cell HL-60 through a reactive oxygen species-dependent mechanism. Food Chem Toxicol 50: 590-596, 2012.

28. Verrax J, Cadrobbi J, Marques C, et al: Ascorbate potentiates the cytotoxity of menadione leading to an oxidative stress that kills cancer cells by a non-apoptotic caspase-3 independent form of cell death. Apoptosis 9: 223-333, 2004. 